Amira M. Safwat MD, Dennis L. Fung MD, Donna C. Bilton MD

\title{
The use of pro- pranolol in rapid sequence anaesthetic induction: optimal time interval for pretreatment
}

Forty patients ASA physical status 1-III were selected and divided into four groups. Group 1, Control, received saline pretreatment five minutes prior to rapid sequence induction and intubation, while Groups $I I, I I I$ and $N$ received propranolol $0.01 \mathrm{mg} \cdot \mathrm{kg}^{-1} \mathrm{IV}$ two, five or eight minutes prior to induction and intubation. Measurements of heart rate $(H R)$, arserial blood pressure $(A B P)$ were recorded as baseline values and at one, two, five, eight and 20 minutes, and simultaneous venous samples were withdrawn for propranolol levels. Calculated rate pressure product (RPP) showed best haemodynamic control in Group III. Serum propranolol levels were under $5 \mathrm{ng} \cdot \mathrm{ml}^{-1}$ in Group III and undetectable in Group IV. Our data show that the optimal time interval between IV propranolol administration and intubation was five minutes.

\section{Key words}

SYMPATHETIC NERVOUS SYSTEM, SYMPATHOLYTIC AGENTS: propranolol; ANAESTHETIC TECHNIQUES: rapid sequence induction; COMPLICATIONS: hypertension, tachycardia.

From the Department of Anaesthesiology, University of Califomia, School of Medicine, Sacramento, California. Address correspondence to: Dr. Amira M. Safwat, University of Califomia, Davis Medical Center, Department of Anesthesiology, 2315 Stockton Boulevard, Sacramento, California 95817.
In a previous study, ${ }^{1}$ we found that propranolol effectively controlled the heart rate (HR), systolic pressure (SP) and rate pressure product (RPP) during laryngoscopy and sternotomy in patients undergoing coronary artery bypass graft surgery.

The purpose of the present study was to determine the optimal time interval between propranolol administration and tracheal intubation during rapid sequence induction.

\section{Methods}

The study protocol was approved by the Human Research Committee of the University of California, Davis, and informed consent was obtained from each patient.

Patients were selected for the study meeting the following criteria: (1) ASA Physical Status Class I-III; (2) ages between 21-60; (3) elective surgery. The following were criteria for exclusion: (1) pregnancy; (2) history of asthma and hay fever; (3) history of drug abuse; (4) treatment with tricyclic antidepressants or reserpine; (5) atrioventricular conduction abnormalities and bradycardia; (6) coronary artery disease.

Forty patients were randomly allocated into four groups. Group I, Control, received pretreatment with saline five minutes before endotracheal intubation. Groups II, III and IV received intravenous propranolol $\left(0.01 \mathrm{mg} \cdot \mathrm{kg}^{-1}\right)$ two minutes, five minutes or eight minutes respectively prior to tracheal intubation.

There were two hypertensive patients, one in Group 1 and another in Group III. Both had their blood pressure well controlled with antihyperten- 
TABLE I Patient characteristics

\begin{tabular}{llllll}
\hline Group & $N$ & $\begin{array}{l}\text { Sex } \\
(\text { MIF })\end{array}$ & Age & $\begin{array}{l}\text { Weight } \\
(\mathrm{kg})\end{array}$ & $\begin{array}{l}\text { Heighr } \\
(\mathrm{cm})\end{array}$ \\
\hline I & 10 & $3 / 7$ & $33 \pm 3.6$ & $76 \pm 5.0$ & $172 \pm 3.6$ \\
II & 10 & $5 / 5$ & $33 \pm 2.3$ & $68 \pm 5.3$ & $169 \pm 4.0$ \\
III & 10 & $5 / 5$ & $37 \pm 5.0$ & $70 \pm 6.6$ & $171 \pm 4.6$ \\
IV & 10 & $6 / 4$ & $36 \pm 3.3$ & $74 \pm 5.0$ & $172 \pm 3.0$
\end{tabular}

There is no significant difference between patient group characteristics. (Analysis of variance.)

sive medication. No patient was receiving propranolol or other beta blockers.

There were no restrictions on the choice of the premedicant agents nor on the anaesthetic agent used for maintenance. The induction was carried out in the following manner: the patient was oxygenated with 100 per cent $\mathrm{O}_{2}$ via face mask; d-tubocurarine ( $3 \mathrm{mg}$ ) was given, followed within five minutes by sodium thiopentone $\left(5 \mathrm{mg} \cdot \mathrm{kg}^{-1}\right)$, and succinylcholine $\left(1.5 \mathrm{mg} \cdot \mathrm{kg}^{-1}\right)$, all given intravenously. After tracheal intubation, ventilation was controlled and general anaesthesia was continued with a variety of other agents.

Observations were made periodically before and at one, two, five, eight and 20 minutes after the pretreatment. One investigator who was blind to the nature of the pretreatment measured and recorded $\mathrm{HR}$ and arterial blood pressure (ABP), and observed the ECG for arrhythmias. HR was read directly from the digital display of a Tektronix model 512 monitoring scope. ABP was recorded by pressure cuff and auscultation. Venous blood samples were withdrawn at each observation point and the serum was analyzed for propranolol by Shand's ${ }^{2}$ adaptation of the fluorometric method of Black. Drug analyses were performed by Ayerst Laboratories. In their laboratory, the recovery of propranolol from serum during extraction is $84.8 \pm 0.9$ per cent (SD), and the mean differences between duplicate samples is $3.98 \mathrm{ng} \cdot \mathrm{ml}^{-1} \pm 0.76 \mathrm{ng} \cdot \mathrm{ml}^{-1}$ (SD). Consequently, the lower limit of detection was considered to be $5 \mathrm{ng} \cdot \mathrm{ml}^{-1}$ propranolol base. A scanning spectrofluorometer was used to identify drugs that might interfere with fluorometric analysis. Only one of the propranolol metabolites, $\mathrm{N}$-desisopropyl propranolol, is known to fluoresce, but this substance is ordinarily produced in small amounts and would probably not be a significant confounding factor during distribution phase of a bolus injection.

HR, SP, and RPP were expressed as per cent of control values. Group means were tested for significant differences using one way analysis of variance and least significant difference methods with 95 per cent confidence levels and 35 degrees of freedom. $P$ values less than 0.05 were considered significant.

\section{Results}

There were no significant differences between the patient group characteristics as shown in Table I (analysis of variance). No statistical difference was found between group control values for HR, SP, RPP or mean arterial pressure. There were no instances of bradycardia, hypotension or wheezing in the pretreated patients. The Group I hypertensive patient and four other patients in that group developed extrasystoles (PVC's or PAC's) which were transient and did not require treatment other than deepening of the level of anaesthesia after intubation. Only two patients in the pretreatment groups developed extrasystoles (both in Group II). The haemodynamic responses to intubation were of a lesser degree in the three propranolol pretreated groups, with best results seen in Group III. RPP increased significantly less after intubation in Group III as compared to Groups I and II (see Table II). The increase in RPP after intubation in Group III was 42 per cent, which was due to a 33 per cent increase in HR and an eight per cent increase in SP. The increase in RPP was 113,101 and 64 per cent in Groups I, II and IV respectively.

Serum propranolol levels were highest one and two minutes after IV administration, but were at the lower limit of detection at five minutes and undetectable twenty minutes after administration (Table III).

\section{Discussion}

Beta adrenergic antagonists have been shown to attenuate the cardiovascular responses to noxious stimuli. Prys-Roberts et al. ${ }^{3,4}$ demonstrated the protection offered by practolol against the undesirable sequellae of laryngoscopy and intubation, and from myocardial ischaemia in two groups of hypertensive patients. Recently, Coleman and Jordan 5 and Safwat et al. ${ }^{1}$ have demonstrated the efficacy of 
TABLE II Preanaesthetic control values for variables measured and \% increase following tracheal intubation

\begin{tabular}{|c|c|c|c|c|c|c|}
\hline Group & $\begin{array}{l}R P P \\
\left(b p m \times \text { torr } \times 10^{3}\right)\end{array}$ & \% Increase & $\begin{array}{l}H R \\
(b p m)\end{array}$ & $\%$ Increase & $\begin{array}{l}S B P \\
\text { (torr) }\end{array}$ & \% Increase \\
\hline ] & $9.5 \pm 1.3$ & $113 \pm 21$ & $74 \pm 5.6$ & $63 \pm 11$ & $127 \pm 7$ & $27 \pm 10$ \\
\hline 11 & $9.1 \pm 0.9$ & $101 \pm 22$ & $75 \pm 5.7$ & $31 \pm 18$ & $120 \pm 3.6$ & $26 \pm 8$ \\
\hline III & $9.8 \pm 1.1$ & $42 \pm 13^{*}$ & $68 \pm 4$ & $33 \pm 17$ & $126 \pm 5.6$ & $8 \pm 6$ \\
\hline IV & $10.2 \pm 0.9$ & $64 \pm 19$ & $86 \pm 7$ & $37 \pm 12$ & $129 \pm 6.3$ & $20 \pm 6$ \\
\hline
\end{tabular}

Mean value \pm SEM.

* = Group Ill had a significantly lower RPP than Groups I and II.

intravenous metoprolol and propranolol respectively in controlling heart rate and blood pressure during anaesthesia.

However, the timing between IV propranolol administration and noxious stimulation has not been studied. We chose tracheal intubation during rapid sequence induction of anaesthesia as our model to assess the optimal time interval between propranolol administration and application of a noxious stimulus.

Our data show that propranolol pretreatment prior to tracheal intubation during rapid sequence induction attenuates the increases in RPP. Although the RPP has been criticized for its inaccuracy in predicting myocardial oxygen consumption $\left(\mathrm{MVO}_{2}\right)$ in anaesthetized patients, ${ }^{5}$ it still represents one of the most valid indices we have in measuring myocardial work (which in itself relates closely to $\mathrm{MVO}_{2}$ ).

Although in our earlier study ${ }^{1}$ the control of RPP was mainly due to the control in $\mathrm{HR}$, in this study the control of RPP was mainly due to the control of $A B P$. This difference in results could be related to differences in anaesthetic techniques, wherein the earlier study patients received more anaesthetic agents prior to laryngoscopy, which was performed only after a decrease in HR following beta block-

TABLE III Propranolol levels

\begin{tabular}{ll}
\hline Time frominjection & Propranolol level \\
\hline $1 \mathrm{~min}$ & $31.8 \pm 23.8 \mathrm{ng} \cdot \mathrm{ml}^{-1}$ \\
$2 \mathrm{~min}$ & $16.2 \pm 7.5 \mathrm{ng} \cdot \mathrm{ml}^{-1}$ \\
$5 \mathrm{~min}$ & $7.5 \pm 0.6 \mathrm{ng} \cdot \mathrm{ml}^{-1}$ \\
$8 \mathrm{~min}$ & $6.0 \pm 1.7 \mathrm{ng} \cdot \mathrm{ml}^{-1}$ \\
$20 \mathrm{~min}$ & undetectable \\
\hline $\mathrm{n}=30$. & \\
Lower limit of detection was $5 \mathrm{ng} \cdot \mathrm{ml}^{-1}$.
\end{tabular}

ade. Also in this study, the reflex tachycardia seen after sodium thiopentone administration probably could not be blocked by such small doses of propranolol.

The dose of propranolol administered in this study was a conservative dose, yet was effective in minimizing the RPP response to tracheal intubation and side effects were not observed. A larger dose might be even more effective, but the risk of side effects needs to be determined.

It is of interest to note that the plasma levels of the drug did not correlate with the haemodynamic responses seen. Levels of $100 \mathrm{ng} \cdot \mathrm{ml}^{-1}$ after IV administration produce maximal effective beta blockade. ${ }^{7}$ Whereas optimal haemodynamic control was achieved at five minutes, propranolol plasma levels were insignificant. This paradox needs further examination. Possibly, the degree of beta receptor blockade is not reflected by plasma propranolol concentration because of rapid distribution and uptake by the tissues and receptors. In support of our findings, Lochan et al. showed a maximal antitachycardic effect to isoproteronol five minutes after IV administration of propranolol and oxprenolol. $^{8}$

Our findings of maximal propranolol levels at one minute and barely detectable levels at five minutes after IV administration are in agreement with those of Romagnoli and Keats. ${ }^{9}$ Additionally, our study shows that at the dose administered $\left(0.01 \mathrm{mg} \cdot \mathrm{kg}^{-1}\right)$ there was no apparent interaction with other anaesthetic agents.

We conclude (1) the optimal time interval between propranolol pretreatment and tracheal intubation, or any noxious stimulus, is five minutes; (2) propranolol may be a useful pretreatment for rapid sequence induction in emergency surgery. 
Acknowledgements

The authors wish to thank John H. Eisele, Jr., M.D. and John A. Reitan, M.D. for their excellent assistance in reviewing this manuscript, and Ayerst Laboratories for performing the drug analyses.

\section{References}

1 Safwat AM, Reitan JA, Misle GR, Hurley EJ. Use of propranolol to control rate-pressure product during cardiac anesthesia. Anesth Analg 1981: 60: 732-5.

2 Shand DG, Nucholls EM, Oates JA. Plasma propranolol levels in adults with observations in four children. Clin Pharmacol Ther 1970; 11: 112-20.

3 Prys-Roberts C, Foex $P$, Biro GP, Roberts JG. Studies of anaesthesia in relation to hypertension. $\mathrm{V}$. Adrenergic beta-receptor blockade. Br J Anaesth 1973; 45: 671-81.

4 Prys-Roberts $C$, Meloche R. Management of anaesthesia in patients with hypertension or ischemic heart disease. Int Anesthesiol Clin 1980; 18: 181217.

5 Coleman AJ, Jordan $C$. Cardiovascular responses to anaesthesia: Influence of beta-adrenoreceptor blockade with metoprolol. Anaesthesia 1980; 35: 972.

6 Sonntag H, Laser R. Myocardial blood flow and oxygen consumption during high-dose fentanyl anesthesia in patients with coronary artery disease. Anesthesiology 1982; 56: 417-22.

7 Coltart DJ, Shand DG. Plasma propranolol levels in the quantitative assessment of B-adrenergic blockade in man. Br Med J 1970; 3: 731-4.

8 Lochan R, Silke B, Taylor SH. Speed of onset of pharmacodynamic activity of propranolol, practolol, oxprenolol and metoprolol after intravenous injection in man. Br J Clin Pharmacol 1981; 12: 721-4.

9 Romagnoli A, Keats AS. Plasma and atrial propranolol after preoperative withdrawal. Circulation 1975; 52: 1123-7.

\section{Résumé}

Quarante patients classés ASA I à III ont été choisis et répartis en quatre groupes. Le groupel (groupe contrôle) a reçu un prétraitement de soluté salin cinq minutes avant l'induction et l'intubation en séquence rapide, alors que les groupes II. III et IV ont reçu du propranolol $0.01 \mathrm{mg} \cdot \mathrm{kg}^{-1}$ intraveineux deux, cinq et huit minutes avant l'induction et l'intubation. Les mesures de la fréquence cardiaque $(H R)$ et de la pression artérielle $(A B P)$ ont été enregistrées a la période contrôle et. ensuite, à une, deux, cing, huit et vingı minutes; au même temps, des échantillons de sang étaient prélcvés pour déterminer les niveaux plasmatiques de propranolol. Les produits fréquence-pression (RPP) se sont montrés plus stables dans le groupe III. Les niveaur plasmatiques de propranolol étaient inférieurs a $5 \mathrm{ng} \cdot \mathrm{ml}^{-1}$ dans le groupe III et non décelables dans le groupe IV. Ces données montrent qu'un intervalle de cinq minutes entre l' administration du propranolol intraveineux et l'intubation est souhaitable. 